\title{
Structural Characterization of a Gold/Serum Albumin Complex
}

Alessandro Pratesi, ${ }^{a}$ Damiano Cirri, ${ }^{a}$ Dolores Fregona, ${ }^{b}$ Giarita Ferraro, ${ }^{a}$ Anna Giorgio, ${ }^{c}$ Antonello Merlinoc, ${ }^{*}$ and Luigi Messoria, ${ }^{*}$

\footnotetext{
a Laboratory of Metals in Medicine (MetMed), Department of Chemistry “U. Schiff”, University of Florence, via della Lastruccia 3, 50019 Sesto Fiorentino, Italy. *luigi.messori@unifi.it

b Department of Chemical Sciences, University of Padova, Via Marzolo 1, 35131 Padova, Italy

c Department of Chemical Sciences, University of Naples Federico II, via Cinthia, 80126 Napoli, Italy *antonello.merlino@unina.it,
}

Materials 


\section{Materials}

Defatted BSA, free of fatty acid, was purchased by Sigma Chemical Co and further purified according to Curry and co-workers. ${ }^{1}$ AuL 12 was synthetized as previously described. ${ }^{2}$ 1HNMR spectrum was in agreement with the literature data.

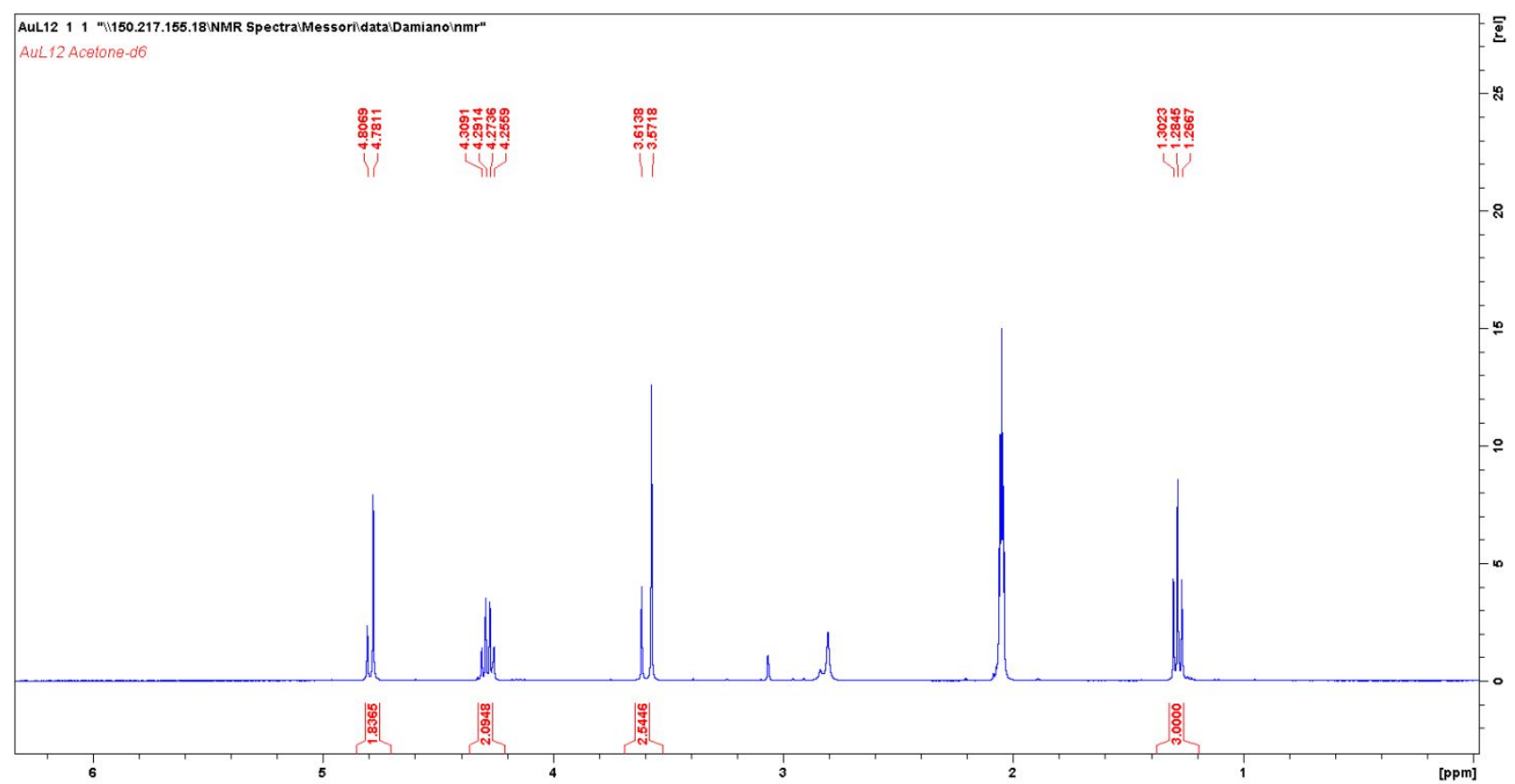

${ }^{1} \mathrm{HNMR}(400.13 \mathrm{MHz} ; 298 \mathrm{~K}): 4.78(\mathrm{~s} ; 2 \mathrm{H}) ; 4.28$ (q; 2H); 3.57 (s; 3H); $1.28(\mathrm{t} ; 3 \mathrm{H})$

\section{UV-Vis absorption spectroscopy}

UV-Vis spectra were recorded on a Varian Cary 50 UV-Vis spectrophotometer (Varian, Palo Alto, CA, USA) in the range of $200-700 \mathrm{~nm}$. Stock solution of AuL12 was prepared by dissolving the complex in DMSO. The electronic spectra were recorded diluting a small amount of this freshly prepared stock solution and the relative amount of BSA at a stoichiometric ratio of 3:1 (metal-toprotein). The final concentration of the protein after dilution in $50 \mathrm{mM}$ phosphate, $\mathrm{pH} 7.4$ was $5 \times 10^{-5}$ M. The resulting solution was monitored collecting the electronic spectra over $24 \mathrm{~h}$ at room temperature. 


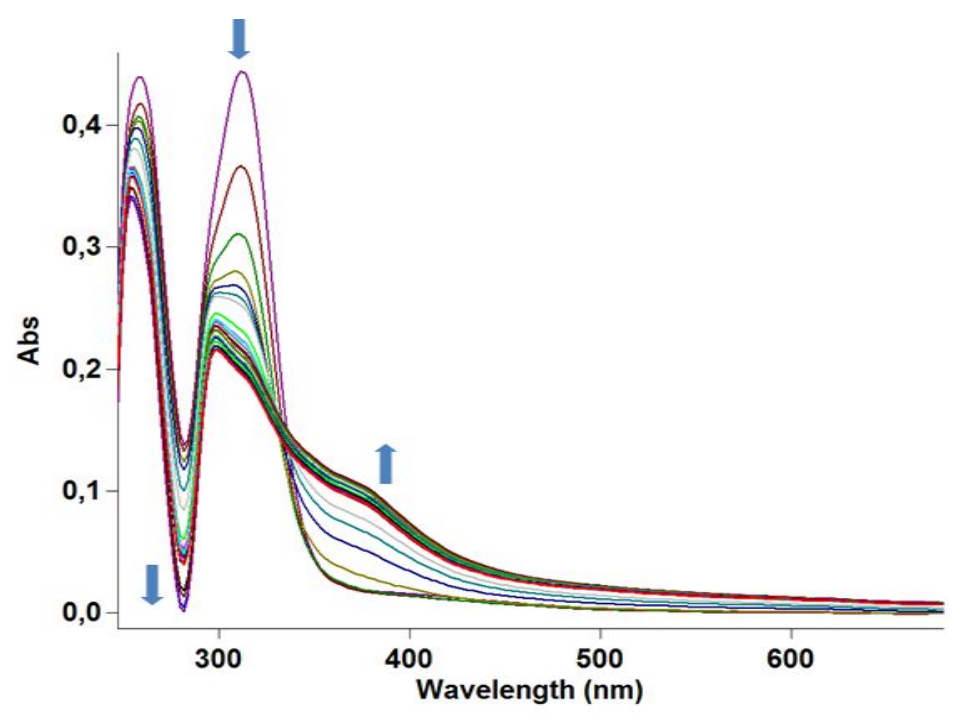

Figure S1. Time-dependent UV-Vis absorption spectra (up to $24 \mathrm{~h}$ at $25^{\circ} \mathrm{C}$ ) of $5 \times 10^{-5} \mathrm{MAuL} 12$ dissolved in $50 \mathrm{mM}$ sodium phosphate buffer $\mathrm{pH} 7.4$ in the presence of BSA at 3:1 metal to protein molar ratio.

\section{Circular dichroism}

In order to characterize the effect of AuL12 binding on the structure of BSA in solution, the spectroscopic properties of the AuL12/BSA adduct were studied by circular dichroism, which is a sensitive technique to monitor the secondary structure of proteins. ${ }^{3}$

To prepare the AuL12/BSA adduct, BSA was mixed with a solution of AuL12 dissolved in DMSO and incubated for 7 days at $4{ }^{\circ} \mathrm{C}$ (final DMSO concentration: $0.44 \%$ ). After the incubation time, each sample was dialysed against $10 \mathrm{mM}$ sodium phosphate buffer $\mathrm{pH} 7.4$ overnight. CD spectral profiles of BSA and of the AuL12/BSA are reported in Figure S2. The spectra show a positive peak at 192 $\mathrm{nm}$ and negative peaks of $\alpha$-helix at $208 \mathrm{~nm}$ and $222 \mathrm{~nm}$. The spectra of BSA and those of the adduct obtained with AuL12 in 1:1 protein to gold compound molar ratio are almost superimposable, suggesting that the formation of the adduct does not induce major conformational changes of the native protein structure. In fact, deconvolution of the CD spectra of AuL12/BSA adduct indicates that 
the $61 \%$ of the residues are involved in the formation of alpha helices/turns, consistently with the value obtained by analysing CD spectra of the wild-type protein (65\%) used as control. On the contrary, when the protein is incubated with the gold compound in 1:3 protein to metal compound molar ratio, the CD spectrum of the adduct presents higher molar ellipticity values, suggesting a loss of secondary structure content. Similar results have been obtained in the absence of DMSO, i.e. preparing the adduct after mixing the protein solution to AuL12 powder.

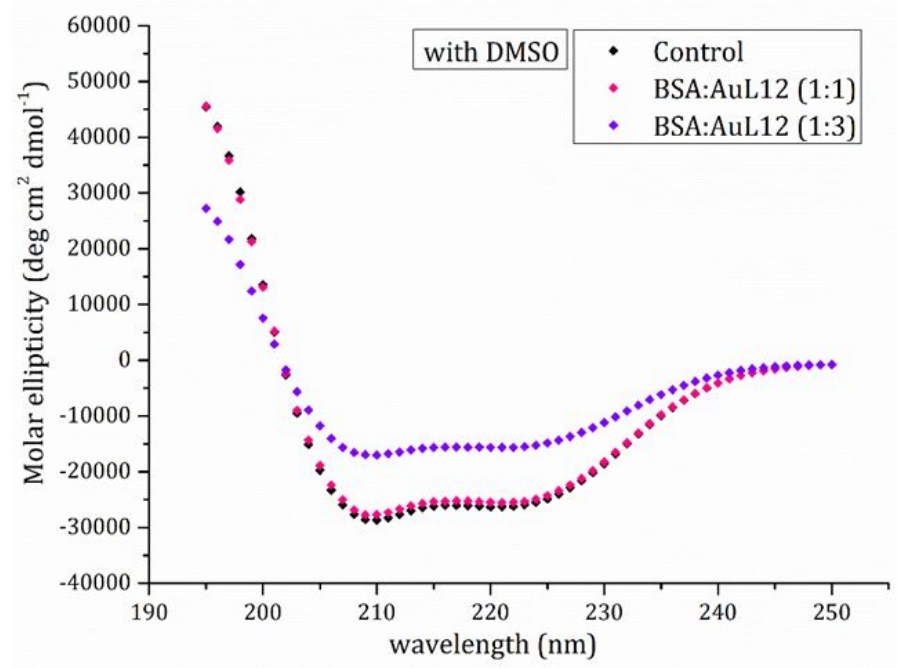

Figure S2. Far-UV CD spectra of BSA (control, black squares) and of AuL12/BSA in a 1:1 (pink squares) and a 1:3 (light purple squares) protein to metal molar ratios. Spectra were collected using a protein concentration of $0.2 \mathrm{mg} \mathrm{mL}^{-1}$ in $10 \mathrm{mM}$ sodium phosphate buffer $\mathrm{pH} 7.4$ and with $0.44 \%$ DMSO.

Then, the thermal denaturation (unfolding) profiles of BSA and of AuL12/BSA were obtained by monitoring the CD signal at $222 \mathrm{~nm}$ as function of temperature (Figure S3) with the aim to characterize the thermal stability of the protein in the absence and in the presence of the gold compound. Thermal unfolding curves have been recorded in the $20-90{ }^{\circ} \mathrm{C}$ range at heating rate 1 ${ }^{\circ} \mathrm{C} / \mathrm{min}$. Results of these experiments are reported in Table S1. Denaturation temperatures clearly 
indicate that the adduct has a reduced thermal stability when compared to BSA (in the presence of the same amount of DMSO).

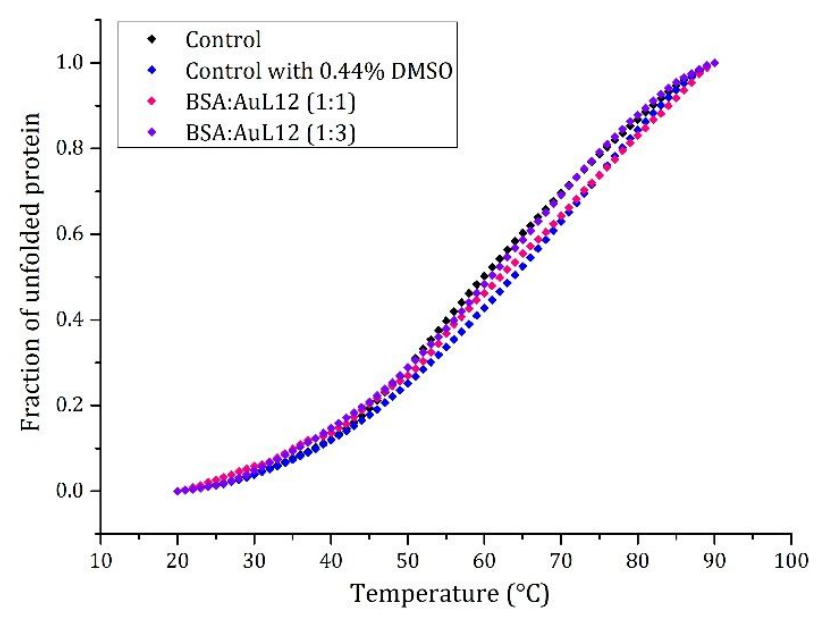

Figure S3. Thermal denaturation profile of BSA incubated with AuL12 in a 1:1 and 1:3 protein to metal molar ratios, compared with the profiles of wild type BSA and BSA incubated with $0.44 \%$ of DMSO. Each curve was obtained plotting the fraction of unfolded protein as function of temperature.

Table S1. Denaturation temperatures (Td) of BSA and AuL12/BSA. Td have calculated from the second derivative of the ellipticity change vs temperature.

\begin{tabular}{|c|c|}
\hline Sample & $\mathbf{T}_{\mathbf{d}}\left({ }^{\circ} \mathbf{C}\right)$ \\
\hline BSA & $69.7 \pm 1.5$ \\
\hline BSA:AuL12 (1:1) & $65.7 \pm 4.0$ \\
\hline BSA:AuL12 (1:3) & $64.7 \pm 0.6$ \\
\hline
\end{tabular}

\section{Crystallization, $X$-ray diffraction data, data processing, structure solution and refinement}

Hanging and sitting-drop vapor diffusion techniques were used to search the crystallization conditions of the adduct formed upon reaction of AuL12 with BSA (co-crystallization protocol ${ }^{4}$ ). Crystallization experiments were set up at $20^{\circ} \mathrm{C}$ in 24 -well plates (linbro plates) using different metal 
compound to protein molar ratio. The best crystals were obtained using the adduct that was prepared in solution using protein to metal molar ratio $1: 3$ and a protein concentration of $50 \mathrm{mg} \mathrm{mL}^{-1}$ in $10 \mathrm{mM}$ sodium phosphate buffer $\mathrm{pH}$ 7.4. The adduct was then crystallized after 3-4 weeks by sitting drop vapor diffusion at room temperature by mixing $1 \mu \mathrm{L}$ of the protein complex with $1 \mu \mathrm{L}$ of the precipitant solution containing $22 \%$ w/v MPEG $5 \mathrm{~K}, 0.2 \mathrm{M} \mathrm{MgCl}_{2}, 0.1 \mathrm{M}$ Tris $\mathrm{HCl} \mathrm{pH} 7.8$, i.e. under conditions similar to those reported for the native protein. ${ }^{5}$

X-ray diffraction data were collected at ESRF (Grenoble, France) using the remote access procedure for the beamline ID30-A1. The diffraction data were scaled and processed using AutoProc. ${ }^{6}$

The crystal structure was solved by the molecular replacement program Phaser ${ }^{7}$ of the CCP4 package using Protein Data Bank (PDB) entry 3V03. ${ }^{8}$ Atomic positions and individual B-factors of AuL12/BSA were refined using REFMAC5. ${ }^{9}$ The structure presents two BSA molecules in the asymmetric unit. Non-crystallographic symmetry restraints and TLS were used to improve the number of observations/number of parameters ratio. Refinement statistics are reported in Table S2. Model building and map inspections were performed using WinCoot. ${ }^{10}$ Figures were generated with Pymol. ${ }^{11}$ The final model refines to $R_{\text {factor }}$ of 0.190 and $R_{\text {free }}$ of 0.253 . The two structures of the a.u. are also very similar: they present a rmsd value as low as $0.13 \AA$. Coordinates and structure factors have been deposited in the Protein Data Bank under the accession code 6RJV. Anomalous data have been provided to Editor and referees and are available on request. Electron density maps of the gold binding sites are reported in Figure S4. 
Table S2. Data collection and refinement statistics

\begin{tabular}{|c|c|c|}
\hline \multicolumn{3}{|c|}{ Data collection statistics } \\
\hline \multicolumn{2}{|l|}{ PDB code } & 6RJV \\
\hline \multicolumn{2}{|l|}{ Space group } & $\mathrm{C} 2$ \\
\hline \multirow{2}{*}{$\begin{array}{r}\text { Unit cell } \\
\text { parameters }\end{array}$} & $a, b, c(\AA)$ & $214.38,44.61,142.61$ \\
\hline & $\alpha, \beta, v\left({ }^{\circ}\right)$ & $\begin{array}{c}90.000,114.003 \\
90.000\end{array}$ \\
\hline \multicolumn{2}{|l|}{ Wavelength $(\AA)$} & 0.9677 \\
\hline \multicolumn{2}{|c|}{ Molecules per asymmetric unit } & 2 \\
\hline \multicolumn{2}{|l|}{ Observed reflections } & $64355(3272)$ \\
\hline \multicolumn{2}{|l|}{ Unique reflections } & $20541(985)$ \\
\hline \multicolumn{2}{|l|}{ Resolution (Å) } & $3.21(3.26-3.21)$ \\
\hline \multicolumn{2}{|l|}{ Completeness (\%) } & $98.6(99.7)$ \\
\hline \multicolumn{2}{|c|}{ Anomalous completeness (\%) } & $92.9(97.3)$ \\
\hline \multicolumn{2}{|l|}{$R_{\text {pim }}$ all I+ and I- } & $0.041(0.377)$ \\
\hline \multicolumn{2}{|l|}{$R_{\text {merge }}$ all I+ and I- } & $0.061(0.584)$ \\
\hline \multicolumn{2}{|l|}{$I / \sigma(I)$} & $13.3(2.2)$ \\
\hline \multicolumn{2}{|l|}{ Multiplicity } & $3.1(3.3)$ \\
\hline \multicolumn{2}{|l|}{$C_{1 / 2}$} & $0.999(0.689)$ \\
\hline \multicolumn{2}{|l|}{$C C^{*}$} & $0.005(0.019)$ \\
\hline
\end{tabular}

Parentheses refer to last shell

\begin{tabular}{|l|c|}
\hline \multicolumn{2}{|c|}{ Refinement statistics } \\
\hline Resolution $(\mathcal{A})$ & $129.52-3.21$ \\
\hline Number of reflections in working set & 19556 \\
\hline Number of reflections in test set & 985 \\
\hline Rfactor/ Rfree/Rall & $0.190 / 0.253 / 0.193$ \\
\hline Non-H atoms used in the refinement & 9321 \\
\hline Occupancy of $A u$ ions & Au1 (0.30) \\
\end{tabular}




\begin{tabular}{|l|c|}
\hline B-factor of $A$ u ions $\left(\AA^{2}\right)$ & $\begin{array}{c}\text { Au1 }\left(111.8 \AA^{2}\right) \\
\text { Au2 }\left(119.3 \AA^{2}\right)\end{array}$ \\
\hline Overall $B$-factor $\left(\AA^{2}\right)$ & 115.46 \\
\hline R.m.s.d. bonds $(\AA)$ & 0.007 \\
\hline R.m.s.d. angles $\left(^{\circ}\right)$ & 1.68 \\
\hline Ramachandran plot statistics & \\
\hline Residues in preferred regions & $1100(95.0 \%)$ \\
\hline Residues in allowed regions & $52(4.5 \%)$ \\
\hline Outliers & $6(0.5 \%)$ \\
\hline
\end{tabular}

A.

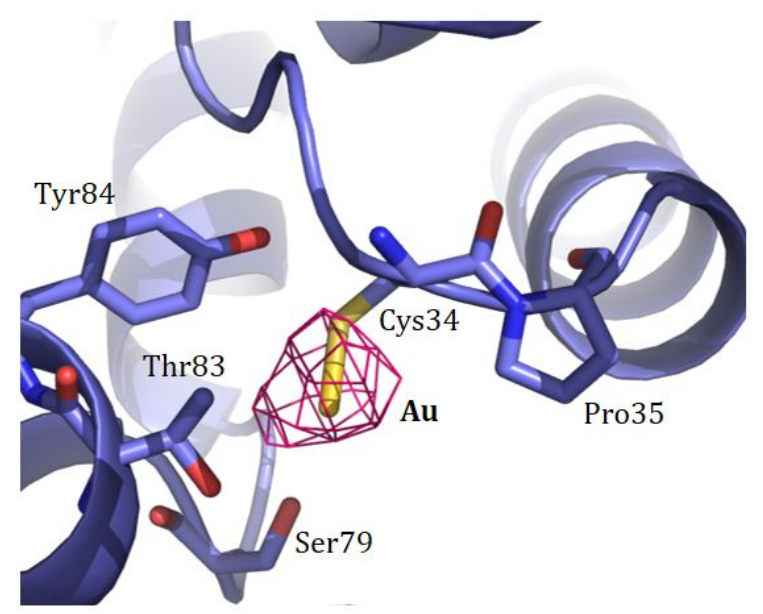

C.

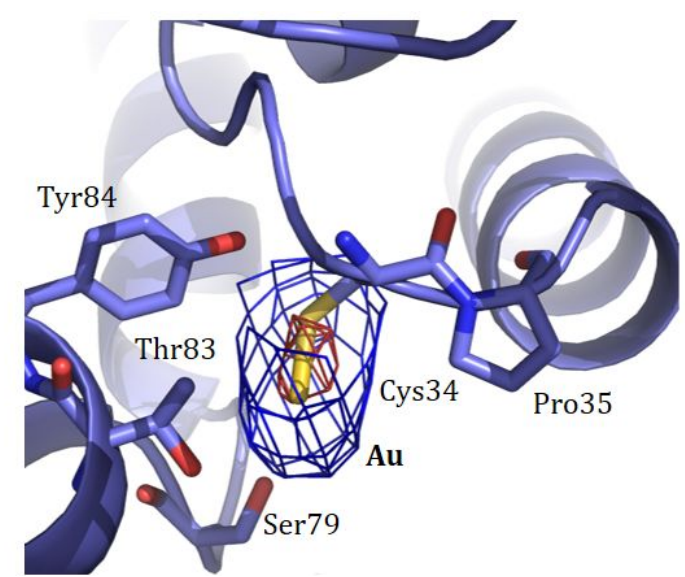

B.

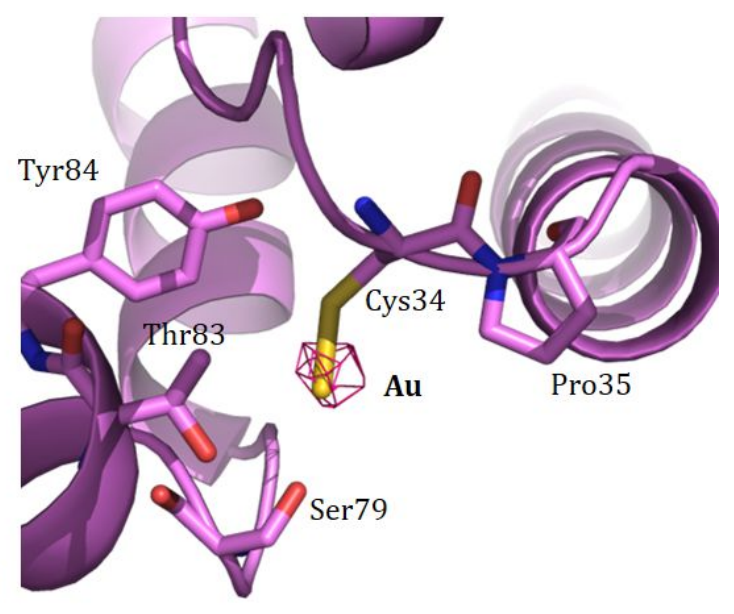

D.

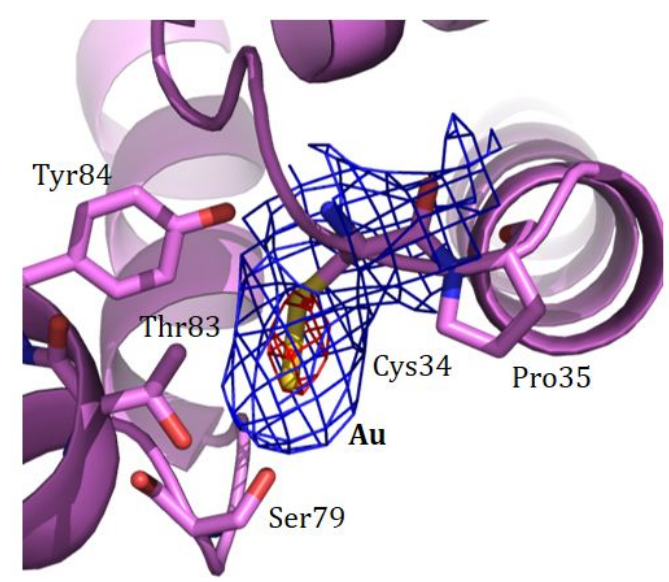

Figure S4. Details of the Au binding sites in the gold/BSA adduct formed upon reaction of AuL 12 with BSA. The two molecules of BSA in the asymmetric unit are reported in violet and pink, respectively. Anomalous difference electron density map is reported at $3.5 \sigma$ (red) in panels $A$ and B. $2 F o-F C$ electron density maps are contoured at $3.5 \sigma$ (red) and $1 \sigma$ (b/ue) in panels $C$ and $D$. 


\section{Electrospray mass spectrometry}

Interactions between AuL12 and Bovine Serum Albumin were assessed by high-resolution ESI-MS as described in our previous works: ${ }^{12}$ a stock solution of AuL12 was prepared in DMSO and an aliquot was added to a solution of BSA in $20 \mathrm{mM}$ ammonium acetate buffer at $\mathrm{pH}$ 6.8. Metal complex to protein ratio was $1: 1$ with final protein concentration $10^{-4} \mathrm{M}$. The AuL12 stock solution in DMSO was reacted also with an aqueous solution of cystine in 1:1 molar ratio and at a final concentration of $10^{-4} \mathrm{M}$. Both reaction mixtures were incubated for $3 \mathrm{~h}$ at $37^{\circ} \mathrm{C}$ and then diluted with LC-MS water at $10^{-6} \mathrm{M}$ final concentration with the addition of formic acid $(0.1 \% \mathrm{v} / \mathrm{v})$. The ESI mass spectra were acquired through direct infusion at $7 \mu \mathrm{L} \mathrm{m^{-1 }}$ flow rate in a TripleTOF® $5600^{+}$mass spectrometer (Sciex, Framingham, MA, U.S.A.), equipped with a DuoSpray® interface operating with an ESI probe (figure S5). The ESI source parameters were optimized and were as follows: positive polarity, Ionspray Voltage Floating 5500 V, Temperature $300^{\circ} \mathrm{C}$, Ion source Gas 1 (GS1) 40; lon source Gas

2 (GS2) 30; Curtain Gas (CUR) 25, Declustering Potential (DP) 200 V, Collision Energy (CE) 10 V. For acquisition, Analyst TF software 1.7.1 (Sciex) was used and deconvoluted spectra were obtained by using the Bio Tool Kit micro-application v.2.2 embedded in PeakView ${ }^{\mathrm{TM}}$ software v.2.2 (Sciex). 


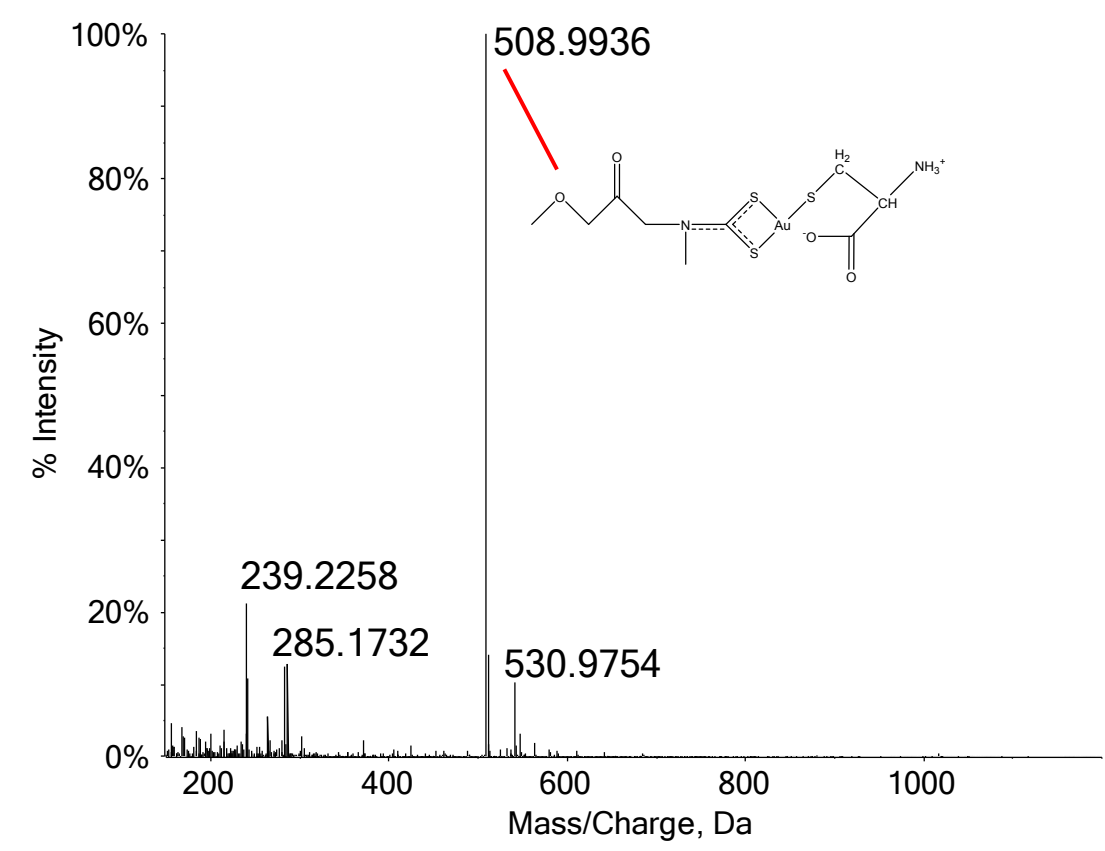

Figure S5. ESI mass spectrum of AuL 12 (stock solution in DMSO) incubated for 2 h with cystine $10^{-5}$ $M\left(1: 1\right.$ molar ratio) at $37^{\circ} \mathrm{C}$ in water.

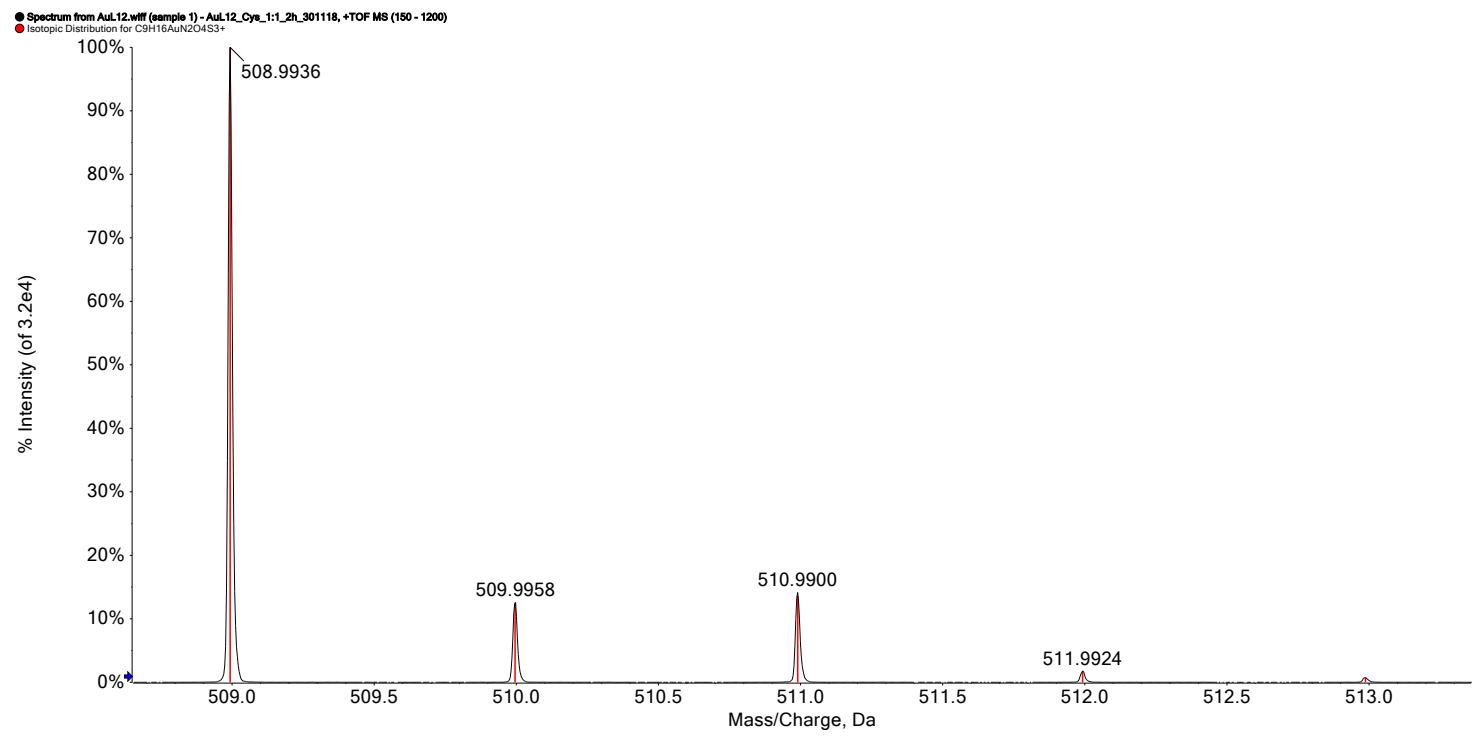

Figure S6. Measured and calculated isotopic pattern for the main adduct of AuL 12 incubated for $2 \mathrm{~h}$ with cystine $10^{-6} \mathrm{M}\left(1: 1\right.$ molar ratio) at $37^{\circ} \mathrm{C}$ in water. Ion type $=[\mathrm{M}]^{+} ;$measured $\mathrm{m} / \mathrm{z}=508.99360$ Da; theoretical $\mathrm{m} / \mathrm{z}=508.99323 \mathrm{Da}$; mass error $=0.7 \mathrm{ppm} ; \mathrm{C}_{9} \mathrm{H}_{16} \mathrm{AuN}_{2} \mathrm{O}_{4} \mathrm{~S}_{3}{ }^{+}$. 


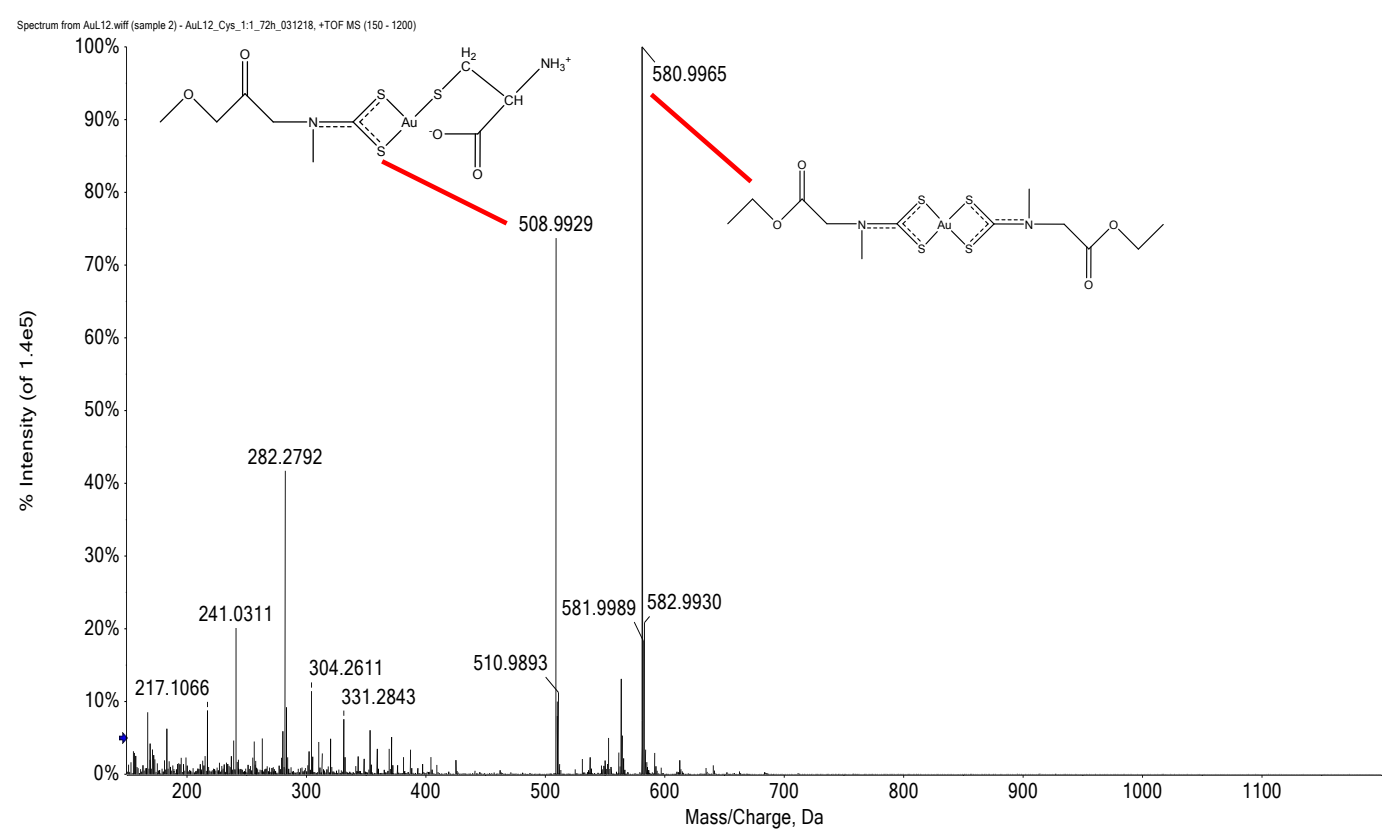

Figure S7. ESI-MS spectrum for AuL 12 incubated for $72 \mathrm{~h}$ with cystine 10-6 M (1:1 molar ratio) at 37 ${ }^{\circ} \mathrm{C}$ in water.

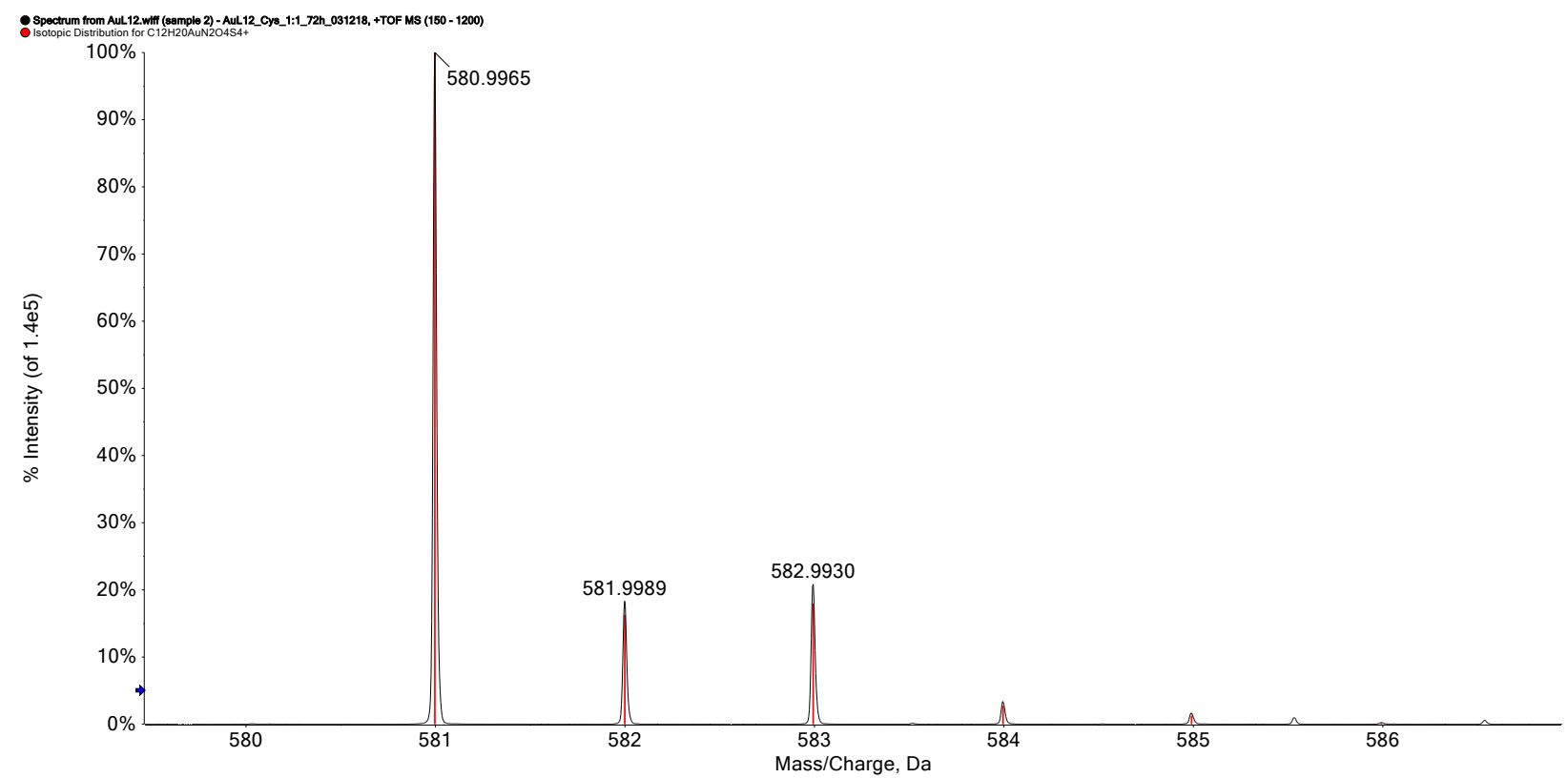

Figure S8. Measured and calculated isotopic pattern for the main adduct of AuL 12 incubated for 72 $h$ with cystine $10^{-6} \mathrm{M}(1: 1$ molar ratio $)$ at $37^{\circ} \mathrm{C}$ in water. Ion type $=[\mathrm{M}]^{+} ;$measured $\mathrm{m} / \mathrm{z}=580.99649$ Da; theoretical $\mathrm{m} / \mathrm{z}=580.99661 \mathrm{Da}$; mass error $=-0.2 \mathrm{ppm} ; \mathrm{C}_{12} \mathrm{H}_{20} \mathrm{AuN}_{2} \mathrm{O}_{4} \mathrm{~S}_{4}{ }^{+}$. 


\section{${ }^{1} H N M R$}

NMR spectra were recorded in a Bruker Avance III 400 spectrometer equipped with a Bruker Ultrashield 400 Plus superconducting magnet and a 5mm PABBO BB-1H/D Z-GRD Z108618/0049 probe.

All acquisitions were performed at room temperature $\left(25+/-2^{\circ} \mathrm{C}\right)$ using Bruker cpmgpr $1 \mathrm{~d}$ sequence. All samples were left to equilibrate for at least 10 min before the data were collected. All spectra were calibrated on solvent residual peak. ${ }^{13}$ Samples were prepared as follows: first of all a $15 \mathrm{mM}$ solution of AuL12 in DMSO- $d_{6}$ was prepared. Then, $15 \mu \mathrm{L}$ of this solution were added respectively to $485 \mu \mathrm{L}$ of $\mathrm{D}_{2} \mathrm{O}$ and to $485 \mu \mathrm{L}$ of a $0.45 \mathrm{mM}$ BSA solution in $\mathrm{D}_{2} \mathrm{O}$. ${ }^{1} \mathrm{H}-\mathrm{NMR}$ spectra were collected with 512 scans for each sample and with and acquisition time of 5.45 seconds.

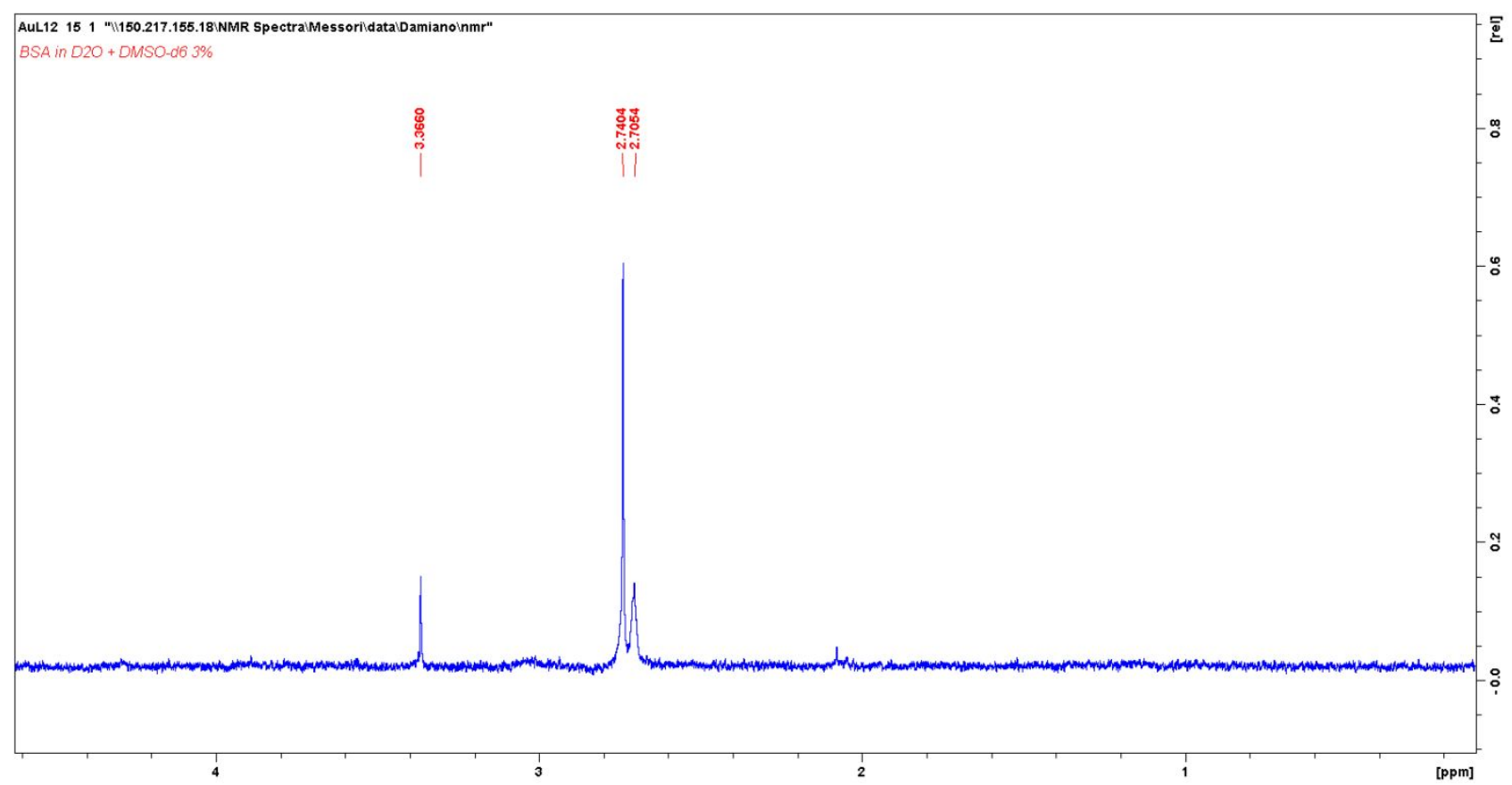

${ }^{1} \mathrm{HNMR}(400.13 \mathrm{MHz}$; 298K; cmpgpr1d pulse sequence) of BSA $0.45 \mathrm{mM}$ : Only BSA impurities (3.36ppm) and solvent residual signals $(2.74 ; 2.71 \mathrm{ppm})$ are visible in the spectrum. 


\section{References}

(1) Curry, S.; Mandelkow, H.; Brick, P.; Franks, N. Crystal structure of human serum albumin complexed with fatty acid reveals an asymmetric distribution of binding sites. Nature Structural Biology, 1998, 5, 827-835.

(2) Nardon, C.; Boscutti, G.; Gabbiani, C.; Massai, L.; Pettenuzzo, N.; Fassina, A.; Messori, L.; Fregona, D. Cell and Cell-Free Mechanistic Studies on Two Gold(III) Complexes with Proven Antitumor Properties. Eur. J. Inorg. Chem., 2017, 12, 1737-1744.

(3) Greenfield, N. J. Using circular dichroism spectra to estimate protein secondary structure. Nat. Protoc., 2006, 1, 2876-2890.

(4) Russo Krauss, I.; Ferraro, G.; Pica, A.; Márquez, J. A.; Helliwell, J. R.; Merlino, A. Principles and methods used to grow and optimize crystals of protein-metallodrug adducts, to determine metal binding sites and to assign metal ligands. Metallomics, 2017, 9, 1534-1547.

(5) Russo Krauss, I.; Sica, F.; Mattia, C. A.; Merlino, A. Increasing the X-ray Diffraction Power of Protein Crystals by Dehydration: The Case of Bovine Serum Albumin and a Survey of Literature Data. Int. J. Mol. Sci, 2012, 13, 3782-3800.

(6) https://www.globalphasing.com/autoproc/manual/autoPROC4.html

(7) Winn, M. D.; Ballard, C. C.; Cowtan, K. D.; Dodson, E. J.; Emsley, P.; Evans, P. R.; Keegan, R. M.; Krissinel, E. B.; Leslie, A. G.; McCoy, A.; McNicholas, S. J.; Murshudov, G. N.; Pannu, N. S.; Potterton, E. A.; Powell, H. R.; Read, R. J.; Vagin, A.; Wilson, K. S. Overview of the CCP4 suite and current developments. Acta Crystallogr. D Biol. Crystallogr., 2011, 67, 235-242.

(8) Majorek, K. A.; Porebski, P. J.; Dayal, A.; Zimmerman, M. D.; Jablonska, K.; Stewart, A. J.; Chruszcz, M.; Minor, W. Structural and immunologic characterization of bovine, horse, and rabbit serum albumins. Mol. Immunol. 2012, 52, 174-182.

(9) Murshudov, G. N.; Skubák, P.; Lebedev, A. A.; Pannu, N. S.; Steiner, R. A.; Nicholls, R. A.; Winn, M. D.; Long, F.; Vagin, A. A. REFMAC5 for the refinement of macromolecular crystal structures. Acta Cryst., 2011, D67, 355-367.

(10) Emsley, P.; Lohkamp, B.; Scott, W. G.; Cowtan, K. Features and development of Coot. Acta Crystallogr. D Biol. Crystallogr., 2011, 66, 486-501. 
(11) DeLano W. L. The PyMOL Molecular Graphics System. Version 1.3r1, 2010, Schrödinger, LLC, New York.

(12) Michelucci, E.; Pieraccini, G.; Moneti, G.; Gabbiani, C.; Pratesi, A.; Messori, L. Mass spectrometry and metallomics: A general protocol to assess stability of metallodrug-protein adducts in bottom-up MS experiments. Talanta, 2017, 167, 30-38.

(13) Gottlieb, H. E.; Kotlyar, V.; Nudelman, A. NMR Chemical Shifts of Common Laboratory Solvents as Trace Impurities. J. Org. Chem., 1997, 62, 7512. 